\title{
PRE-EMPTIVE RIGHTS IN CLOSE CORPORATIONS
}

The doctrine of pre-emptive rights in the issuance of stock was developed to protect existing shareholders from impairment of their voting power and dilution of their equity interest through issuance below value. ${ }^{1} \mathrm{In}$ a public-issue corporation, protection against this latter result may be afforded by sale of the subscription rights. However, in a close corporation ${ }^{2}$ there is no ready market for these rights and the alternative of sale may thus not be available.

The Illinois case of Hyman v. Velsicol Corp. ${ }^{3}$ presents a striking example of the possibilities for dilution in a close corporation. The plaintiff shareholder was seeking to enjoin a proposed recapitalization consisting of the issuance of $\$ 100$ par stock at par, claiming it was really worth $\$ 7,500.00$ a share. He was given subscription rights but did not exercise them. In order to do so it would have been necessary to raise $\$ 136,000.00$ in less than eleven days. The court upheld the recapitalization sayng that it "was not an abuse of the discretion vested in the majority stockholders or directors and was not fraudulently oppressive.""

From the minority shareholders' point of view the ideal solution would be a veto power over the issuance ${ }^{5}$ of any new stock. This, however, involves a departure from what has come to be accepted as the traditional view of corporate powers, i.e., separation of management from ownership and substituting in its place a division of authority along partnership lines. ${ }^{6}$ Thus, the familiar controversy is raised as to whether investors may successfully adopt the corporate form in dealing with others and still treat each other as partners. Courts have

${ }^{1}$ Ballantine, Corporations $\$ 209$ (rev. ed., 1946).

2 The term "close corporation" has no single meaning. For the purposes of this comment it will be used to refer to a corporation whose stock has no ready market.

In the United States the term is often used to signify a corporation in which ownership and management are substantially identical. Israels, The Close Corporation and the Law, 33 Cornell L.Q. 488 (1948). In other countries special types of corporations are provided for by statute and the distinction is generally drawn between enterprises which are privately financed and those which are financed by the general public. Consult The English Companies Act, 11 \& 12 Geo. VI, c. 38 (1948). This latter concept is similar to the distinction used in this comment.

3342 Ill. App. 489, 97 N.E. 2d 122 (1951). Appeal was denied by the Illinois Supreme Court, 346 Ill. App. XIV (1952).

4 Ibid., at 497, 125-26.

"By the "issuance" of stock is meant the actual transfer of it to the prospective shareholder and not simply its authorization. A distinction is necessary since the Illinois Business Corporation Act includes in its definition of "issued" shares those which are authorized but not outstanding. Ill. Stat. Ann. (Smith-Hurd, 1955) c. 32, § 157.2(g).

- The idea that loss of direct control on the part of the owners has traditionally been a basic distinction between corporations and partnerships is not as historically sound as is generally thought. Originally, basic changes, such as the issuance of new shares, required a unanimous vote from the shareholders, although this was altered by subsequent statutes. Israels, The Close Corporation and the Law, 33 Cornell L.Q. 488, 498 (1948). 
not been too receptive to such arrangements. ${ }^{7}$ However, writers in the corporate field generally agree that there is no reason for rigidity and urge that agreements affording the minority shareholders more direct control should be enforced. ${ }^{8}$

Some state statutes specifically provide that the articles of incorporation or the by-laws can require a greater majority for given acts than is required by the statute. ${ }^{9}$ In construing their statute a New York court has said that it "establishes the legality of an agreement between all stockholders requiring unanimous consent for stockholders or directors to act." ${ }^{\prime 10}$

Furthermore, not all of the courts have taken a paternal attitude toward corporate purity and even in the absence of a statute an agreement between the parties may be enforced without regard to the corporate form. For example, in Mérlino v. West Coast Macaroni Manufacturing Co. ${ }^{11}$ a California court enforced an agreement between the sole shareholders, each owning fifty per cent of the stock, to the effect that the plaintiff, as long as he retained his stock, was to control and manage a wholly owned subsidiary, for which service he was to

7 The general attitude is exemplified by Cohen v. Mahoney, 160 Misc. 196, 197-98, 289 N.Y. Supp. 802, 803 (1936): "It is a not infrequent assertion that a partnership exists under the guise of a corporation ... but once they adopt the corporate form and gain the right to the immunities that result they suffer the consequence of limited control and must seek their remedies through the corporation." Cf. Hennessey v. During, 124 N.Y.S. 2d 266 (S. Ct., 1953).

The New York courts have generally been in accord with the attitude expressed in the Cohen case. There were, however, two earlier exceptions: Clark v. Dodge, 269 N.Y. 410, 199 N.E. 641 (1936), and Danzig v. Lacks, 235 App. Div. 189, 256 N.Y. Supp. 769 (1932). In the latter case plaintiff was seeking to enjoin an issue of stock which he claimed had diluted his holding. The court held that he had stated a cause of action when he alleged a breach of an agreement between the three stockholders that he would never own less than 30 per cent of the company. Unfortunately, this aspect of the case has gone unnoticed. Finally, in response to Benintendi v. Kenton Hotel, Inc., 294 N.Y. 112, 60 N.E. 2d 829 (1945), where the court struck down an agreement between two sole stockholders of a corporation requiring unanimity for all stockholders' or directors' actions, the legislature, in 1948, passed a statute allowing such arrangements. N.Y.L. (1948) c. 862, \$1, as amended, N.Y. Stock Corp. Law (McKinney's, 1951) §9.

${ }^{8}$ Consult Hornstein, Judicial Tolerance of the Incorporated Partnership, 18 Law \& Contemp. Prob. 435, 441 (1953); O'Neal, Giving Shareholder's Power to Veto Corporate Decisions: Use of Special Charter and By-Law Provisions, $18 \mathrm{Law} \&$ Contemp. Prob. 451 (1953); Israels, The Close Corporation and the Law, 33 Cornell L.Q. 488 (1948).

A completely separate statute had been proposed for close corporations in New York. Consult Winer, Proposing a New York "Close Corporation Law," 28 Cornell L.Q. 313 (1943). Section 34 of the proposed act would prevent the issuance of any new shares without the previous unanimous consent of the stockholders. Tbid., at 338.

Of course the granting of veto powers increases the chance of corporate deadlock. F. Hodge O'Neal has suggested provisions for arbitration as the most hopeful method of dealing with this problem-Resolving Disputes in Closely Held Corporations: Intra-Institutional Arbitration, 67 Harv. L. Rev. 786 (1954).

9 E.g., Del. Code Ann. (1953) tit. 8, §216; Tll. Stat. Ann. (Smith-Hurd, 1954) c. 32, \$163a92; N.Y. Stock Corp. Law (McKinney's, 1951) §9.

${ }^{10}$ Jos. H. Carter, Inc. v. Carter, 205 Misc. 192, 195, 127 N.Y.S. 2d 518, 521 (S. Ct., 1953).

1190 Cal. App. 2d 106, 202 P. 2d 748 (1949). 
receive $\$ 9,000.00$ a year. The court did not go into the question of whether such an agreement was enforceable in an ordinary corporation but held that the plaintiff had stated a cause of action when he alleged the agreement and the fact that the business had been run like a partnership. There could "be no question but that an agreement between stockholders who own substantially all of the stock of a corporation is enforceable against the contracting parties and the corporation."12 Presumably this broad language would cover a requirement of unanimity for the issuance of new stock.

There are only a few cases directly dealing with the problem of protecting, in the absence of an enforceable agreement, the close-corporation shareholder from a dilution in the value of his stock. In most of these cases the decisions were based on collateral points, ${ }^{13}$ and there has thus been only limited opportunity to formulate a policy on the question of whether these shareholders are to have any protection beyond their pre-emptive rights. In order to gain perspective, the question will be approached by examining first a situation in which there are no pre-emptive rights and comparing the results with the close corporation cases in which the rights are worthless because the shareholder cannot or does not want to exercise them.

Bodell v. General Gas \& Electric Corp..$^{14}$ is a leading Delaware case involving a public-issue corporation in which the pre-emptive rights had been waived. Suit was brought by class $B$ shareholders to enjoin the issue of new non-par shares to class A stockholders at $\$ 25.00$ a share. Another issue of the same stock had been issued to both classes at $\$ 45.00$. The court stated that "[t]he mere showing of the two prices without satisfactory explanation undoubtedly would entitle the complainants to relief." 15 Thus, upon the mere showing that the stock was issued below value the court was ready to protect the shareholder

12 Ibid., at 111, 751; cf. Conover v. Smith, 83 Cal. App. 227,256 Pac. 835 (1927); Thompson v. Thompson, 214 S.C. 61,51 S.E. 2d 169 (1948). Consult also Kauffman v. Meyberg, 59 Cal. App. 2d 730, 140 P. 2d 210 (1943), involving a dispute over stock in a family corporation. The founder had bequeathed the stock equally to his two children but some shares had not been properly recorded. In upholding the bequest the court said that to apply "the technical rules as commonly applied to corporations ... in the case of a close family corporation of two shareholders of equal ownership, would serve to defeat such equality of ownership, impede justice and perpetuate fraud." Ibid., at 739, 215.

${ }^{13}$ In some of the cases the courts in refusing relief state that the plaintiff could have protected himself by selling his rights. This may be taken to mean that the plaintiff had not adequately urged the unmarketability of the stock although the facts suggest that not many of the shares had been traded. Scheirich v. Otis-Hidden Co., 204 Ky. 289, 264 S.W. 755 (1924); Schramme v. Cowin, 205 App. Div. 20, 199 N.Y. Supp. 98 (1923); Bellows v. Porter, 201 F. 2d 429 (C.A. 8th, 1953).

14 15 Del. Ch. 119, 132 Atl. 442 (1926). Accord: Hodgman v. Atlantic Refining Co., 2 F. 2d 893 (D. Del., 1924).

${ }_{15} 15$ Del. Ch. 119, 132, 132 Atl. 442, 448 (1926). A satisfactory explanation was found in the fact that the stock was being issued to the class A shareholders in place of dividends in accordance with a previously announced plan which was formulated to promote further sales of class A stock at a higher price. 
from dilution by what it called an "analogy to that reasoning which underlies the doctrine of preemptive right.".16

A. A. Berle, Jr. has called this underlying policy the doctrine of "equitable contribution." He defines it generally as the "policy of the law that every shareholder shall have contributed to the capital of the corporation on an equitable basis in order to be entitled to share in the earnings and the distribution of dividends." 17 This definition and the term "equitable contribution" are not entirely accurate since the courts are not so much concerned with how much the shareholder has contributed as they are in ascertaining that the corporation has gained something, which, allowing for the discretion of the directors, is equivalent to the value of the stock issued..$^{18}$

Bennett v. Breuil Petroleum Corp., ${ }^{19}$ another Delaware case, involved a close corporation substantially owned by plaintiff and defendant. There the court gave relief on the same grounds as those enunciated in the Bodell case, although the plaintiff had been offered his pre-emptive rights. As director and majority shareholder the defendant had reduced the par value of the stock from $\$ 1.00$ to $\$ 0.40$ and had issued a million shares at that price. The plaintiff claimed the stock was worth between $\$ 2.50$ and $\$ 3.00$ and alleged a fraudulent plan to freeze him out. The court said that if the plaintiff could show that a freeze-out was intended the stock would be cancelled even if issued at full value, presumably referring to a freeze-out in terms of voting power. It went on to state that the allegation of issuance at substantially less than value makes out a case of "constructive fraud." In answer to the defendant's claim that the pre-emptive right protected the shareholder the court said:

This argument is wide of the mark ... because plaintiff has the right not to purchase as well as the right to purchase. But his right not to purchase is seriously impaired if the stock is worth substantially more than its issuing price.20

Thus, it can be said that a disinclination or inability to invest further on the part of a shareholder in a close corporation is analogous to a prior waiver of pre-emptive rights in a public-issue corporation, and the minority shareholder can obtain relief, as in the Bodell case, merely by showing that the stock was issued below value.

In the principal case, Hyman v. Velsicol Corp. ${ }^{21}$ however, the court took the

${ }^{16}$ Ibid., at 131, 447.

${ }^{17}$ Berle and Magill, Cases on Corporation Finance 106 (1942).

18 This ordinarily amounts to the same thing, but the situation in the Bodell case was such that although issuance of stock at $\$ 25.00$ was a violation of the rule of "inequitable contribution," it was upheld because the corporation was benefited collaterally in that by living up to its announced intention it enhanced the value of the stock yet to be issued. Consult note 15 supra.

1999 A. 2d 236 (Del. Ch., 1953).

${ }^{20}$ Tbid., at 240.

21 342 Ill. App. 489, 97 N.E. 2 d 122 (1951), discussed in text supra at p. 697. 
position that the pre-emptive right was exhaustive of the plaintiff's remedies. In answer to the allegation that the stock was issued below value the court said that there was no duty to issue it at value, especially in light of the fact that the plaintiff was not certain that he wanted to exercise his rights. ${ }^{22}$ Although the case has been cited as standing for this proposition, ${ }^{23}$ a closer examination will show that it was dictum.

Velsicol was organized in 1931 to exploit plaintiff's inventions. It was financed by two $\$ 8,000.00$ investments from each of two corporations, Arvey and Transo, which were substantially owned by the defendant officers of Velsicol. The corporation made practically no net profit until 1940 but by 1946 it had an earned surplus of $\$ 352,752.85$. Prior to 1939 Transo and Arvey advanced over $\$ 500,000.00$ to Velsicol, taking back non-interest bearing notes. It was the capitalization of these notes for which most of the stock was issued.

The Chancellor found the plan to be unfair and motivated only by a desire to oppress and defraud the plaintiff. The court rejected this saying that the question of the defendant's state of mind with respect to the plaintiff was immaterial; it was convinced that from the point of view of the corporation a recapitalization at that time was a prudent step. This assertion appears irrelevant, however, since the plaintiff was challenging the method of recapitalization and not its necessity. ${ }^{24}$ Upon close analysis the court was really saying that the recapitalization was done on the best possible basis. In other words, the noteholders were in a position to drive just the bargain they did. Thus, the court stressed the fact that the notes were overdue and that payment could have been demanded at any time. It was not felt that the noteholders were overreaching, in spite of the fact that they were also directors of the corporation. This is shown by the court's denial that the position of the noteholders was similar to that of the Federal Reserve Bank in American Bank \&. Trust Co. v. Federal Reserve Bank, ${ }^{25}$ where the Federal Reserve Bank was enjoined from carrying out a plan by which it intended to coerce the plaintiff into becoming a member of

22 It was not surprising that plaintiff did not want to invest further in the corporation since there had been a sharp falling out between him and the other owners. There had even been litigation over certain patent rights. Velsicol Corp. v. Hyman, 405 IIl. 352,90 N.E. 2d 717 (1950).

${ }^{23}$ Survey of Illinois Law for the Year 1950-1951, 30 Chi.-Kent Rev. 1, 4 (1954).

${ }^{24}$ In several cases the question of whether the corporation needed more capitalization is treated as a pertinent issue. In Gaines v. Long Manufacturing Co., 234 N.C. 340, 67 S.E. 2d 350 (1951), the plaintiff was seeking to enjoin a new issue. The demurrer to the complaint was overruled, but the court treated as necessary the allegation that the business did not need new capital. Cf. Bellows v. Porter, 201 F. 2 d 429 (C.A. 8th, 1953). These cases do not make clear exactly what bearing the need for more capital has on the issue of whether the plaintiff can obtain relief against an issuance of stock below value. The courts, as in the Velsicol case, may be indirectly questioning the allegation that the stock was issued below value. Another possibility is that the courts may consider the gist of the action to be fraud and the question of whether there was a bona fide need for capital would be pertinent as evidence of good faith or bad.

${ }^{25} 256$ U.S. 350 (1921). 
the Federal Reserve system. Thus, comparing the bargaining position of the noteholders with that of the corporation suggests that the exchange of stock for notes was not an unfair bargain. ${ }^{26}$ This leads to the conclusion that the stock was not issued below value and reduces to a dictum the subsequent statement that there was no duty to issue at value.

A strict application of the Velsicol dictum would in effect foreclose the minority shareholder from showing fraud and would lead to extremely harsh results. The plaintiff-stockholder would be prevented from showing that the only purpose of the issue was substantially to destroy its equity interest. The shareholder's only protection would be his ability to match the capital resources of the majority.

In Steven v. Hale-Haas Corp. ${ }^{27}$ the defendant was unsuccessful in his attempt to urge upon the court the theory that the pre-emptive offering had exhausted the minority's rights. The plaintiff was seeking an injunction against the issuance of stock allegedly below value. In answer to the assertion that the pre-emptive rights "removed as a matter of law, all objections to the fact that the stock was issued at less than its value,"28 the court not only responded by treating the issue of bad faith as still being open, but said that the issuance materially below value in itself "may evidence an oppressive scheme directed against minority stockholders." ${ }^{29}$ If the plaintiff is prepared to prove that the purpose of the issue was solely to dilute his equity, it would appear only fair that he should be allowed to do so.

But the further question to be asked is whether it should be necessary to show bad faith in order to obtain relief. Under Bennett v. Breuil Petroleum Co., it would apparently not be necessary to show bad faith. It will be recalled that the court there stated that the allegation of issuance below value made out a case of "constructive fraud." This phrase did not mean simply that bad faith was presumed subject to rebuttal, but that it was irrelevant. Thus the court went on to talk about the "right" of the minority not to purchase the stock, a right which would be impaired if the stock were issued far below value. It seems

\footnotetext{
${ }^{26}$ Unless the plaintiff's claims as to the value of stock were completely groundless it is diffcult to understand how the court could come to the conclusion that there was no overreaching. Part of the plan was a stock split, the reason for which is not discernible, which decreased the par from $\$ 100.00$ to $\$ 10.00$ and decreased the alleged value from $\$ 7,500.00$ to $\$ 750.00$ a share. But either way it was claimed that the stock was worth 75 times its price. Surely the directors could have effected a refunding rather than a capitalization of the notes.

The only explanation seems to be that the court was indulging in a little offhand equity. If the defendants, instead of lending the money to the corporation, and taking back non-interest bearing notes, had capitalized it at the time they would have been in the position in which this case put them. The corporation, it will be remembered, did not begin to make money until 1939 so presumably the stock was worth no more than par when the loans were made. In the court's opinion the statement of the facts pertaining to the notes were set out just before the discussion of the bargaining position of the noteholders, and it was obvious that it felt the origin of the notes was pertinent to the question of overreaching.
}

${ }^{27} 249$ Wis. 205,23 N.W. $2 d 620$ (1946).

${ }^{28}$ Ibid., at 226,630 .

${ }^{29}$ Tbid., at 228, 631. 
unreasonable to suppose that it would allow this "right" to be abrogated by the defendant's innocent state of mind. ${ }^{30}$

In phrasing the minority's protection in terms of a "right" not to have the stock issued below value instead of in terms of fraud, the court did not impinge upon the director's or majority's freedom of action because there can be no legitimate reason for issuing stock below value in a close corporation. The only reason for doing so in any situation pertains to the problems of floating a public issue through subscription rights. The reasons generally given are that it insures the success of the issue or that it has the same psychological effect as a dividend. ${ }^{31}$ These reasons have no application to a close corporation where the stock will be issued to prearranged buyers.

Nor need it be feared that the directors will be put to a delicate decision every time they price a new issue. Presumably the value can only be estimated in terms of a maximum and minimum. The complaining shareholders would have to prove that the stock was issued below the minimum, thus leaving a margin for the discretion of the directors. ${ }^{32}$ This is borne out by the language in the Breuil case itself where the court said that the stock issue must be worth "substantially" more than the issuing price, if an attack on the ground of inadequacy of value is to be successful.

Thus under the Breuil case, the shareholder whose equity is threatened not only has protection beyond his pre-emptive rights but, unlike the case where only voting power is at stake, fraud need not be proved, ${ }^{33}$ nor is good faith a defense. The shareholder's burden is discharged upon a showing that the stock was issued below value. This rule is sound insofar as it gives the shareholder maximum protection without detracting from the directors' or majority share-

${ }^{30}$ Instead of framing this in terms of a right of the minority it could be set out as a fiduciary duty on the part of the directors or majority shareholders not to impair the minority's interest by issuing shares below value. It would be necessary thus to frame the action if the shares were in the hands of bona fide purchasers and the shareholder had to rely on an action for damages against either the directors or the minority shareholders. But by the nature of the problem the shares of the corporation involved will not be transferred quickly and it will almost always be possible to restore the parties to their original position through an action against the corporation and the holders of the stock. Generally the holders will be directors and majority shareholders because most of these cases involve a capitalization of notes held by them.

${ }^{31}$ Guthmann \& Dougall, Corporate Financial Policy 369 (3d ed., 1955). Another possible reason is the actual dilution of the market value of the stock by issuance substantially below value in order to mask the company's prosperity.

32 In the face of the courts' unwillingness to interfere with the business decisions of directors, it would be no light burden for the plaintiff to prove that the value of the stock was substantially above the price set. In the absence of a market, the term "value" is highly elusive. In Gaines v. Long Manufacturing Co., 234 N.C. 331, 67 S.E. 2d 355 (1951), the plaintiff based his case on a showing that the book value of his stock would be diluted. But book value does not pretend to reflect the value of the business and ordinarily the plaintiff will want to make a more conclusive showing. For the problems involved consult Graham \& Dodd, Security Analysis (2d ed., 1940).

${ }^{33}$ Consult Luther v. C. J. Luther \& Co., 118 Wis. 112, 94 N.W. 69 (1903). 
holders' freedom to act for the good of the corporation. Furthermore, the policy of granting relief only upon proof that the stock was issued below value is in accord with the general doctrine that the corporation should receive full value for any shares which it issues.

\section{PRIVILEGED COMMUNICATIONS UNDER RULE 26(b): CONFLICT OF LAWS IN DIVERSITY CASES}

The scope of examination in taking a deposition permitted by Rule 26(b) of the Federal Rules of Civil Procedure is limited to matters "not privileged."1 Where a deposition is being taken in one state for use in an action based on diversity of citizenship pending in a federal district court sitting in another state, ${ }^{2}$ and the witness claims a privilege recognized under the laws of only one of the two states, the United States District Court for the district in which the deposition is being taken is faced with a unique problem of conflict of laws. ${ }^{3}$ It will be the purpose of this comment to suggest a method of analysis by which the courts may best approach the choice-of-law problem presented by the twostate deposition situation in the light of the law of state-created privileges in the federal courts and of the proper weight to be given the requirements of Erie $R$. Co. v. Tompkins.4

The problem may be raised in either of two situations which ultimately must

1 "Unless otherwise ordered by the court as provided by Rule 30(b) [providing for special limitations on the scope of examination, time, place, or manner of taking the deposition, the preservation of secrecy in certain cases, and such orders as may be required in the interests of justice] or (d) [providing relief from unreasonably oppressive, embarrassing, or annoying examination], the deponent may be examined regarding any matter, not privileged, which is relevant to the subject matter involved in the pending action. ..." Fed. Rules Civ. Proc. 26(b).

2 A party to an action pending in a federal district court may, upon proper notice, as provided in Rules $30(a)$ or 31 (a), take the deposition of a witness found or residing in any state. Upon a showing that an action is pending and that the requisite notice has been given, the clerk of the district court for the district in which the deposition is to be taken must issue a subpoena compelling the witness to give his deposition, and the subpoena may require the production of documents. Rule 45(d). If the witness refuses to answer a question, the party proponent may move the court in the district where the deposition is being taken for an order compelling the witness to answer. Rule 37(a). At the hearing on this motion, the witness has an opportunity to justify his refusal, perhaps by making a claim of privilege.

3 The question could come before the court in one of several ways: a motion to quash or restrict the scope of the subpoena, a petition to suppress a deposition already taken, a motion by the party proponent for an order compelling the witness to answer under Rule 37 , or a motion by the proponent for an order citing the witness for contempt. Consult note 2 supra. For examples consult Palmer v. Fisher, 228 F. 2d 603 (C.A. 7th, 1955), discussed in text at p. 705 infra (motion by witness to suppress; cross motion by proponent for contempt citation); Ex parte Sparrow, 14 F.R.D. 351 (N.D. Ala., 1953), discussed in text at p. 706 infra (motion for compelling order under Rule 37). A motion to limit the scope of examination must be made to the court in which the action is pending. Rule $30(\mathrm{~b})$. The trial court might also be faced with the question if objection is made to the introduction in evidence of a deposition containing privileged matter.

4304 U.S. 64 (1938). 